\title{
AHR and NRF2 in Skin Homeostasis and Atopic Dermatitis
}

\author{
Tomohiro Edamitsu ${ }^{1,2}$, Keiko Taguchi ${ }^{1,3,4}\left(\mathbb{D}\right.$, Ryuhei Okuyama ${ }^{2}\left(\mathbb{D}\right.$ and Masayuki Yamamoto ${ }^{1,3,4, *(\mathbb{C})}$ \\ 1 Department of Medical Biochemistry, Graduate School of Medicine, Tohoku University, \\ Sendai 980-8575, Japan; etomohiro@shinshu-u.ac.jp (T.E.); keiko.taguchi.c8@tohoku.ac.jp (K.T.) \\ 2 Department of Dermatology, Shinshu University Graduate School of Medicine, 3-1-1 Asahi, \\ Matsumoto 390-8621, Japan; rokuyama@shinshu-u.ac.jp \\ 3 Department of Medical Biochemistry, Tohoku Medical Megabank Organization, Tohoku University, \\ Sendai 980-8573, Japan \\ 4 Advanced Research Center for Innovations in Next-Generation Medicine (INGEM), Tohoku University, \\ Sendai 980-8573, Japan \\ * Correspondence: masiyamamoto@med.tohoku.ac.jp; Tel.: +81-22-717-8084
}

check for updates

Citation: Edamitsu, T.; Taguchi, K.; Okuyama, R.; Yamamoto, M. AHR and NRF2 in Skin Homeostasis and Atopic Dermatitis. Antioxidants 2022, 11, 227. https://doi.org/10.3390/ antiox11020227

Academic Editor: Gerasimos P. Sykiotis

Received: 27 December 2021

Accepted: 22 January 2022

Published: 25 January 2022

Publisher's Note: MDPI stays neutral with regard to jurisdictional claims in published maps and institutional affiliations.

Copyright: () 2022 by the authors Licensee MDPI, Basel, Switzerland. This article is an open access article distributed under the terms and conditions of the Creative Commons Attribution (CC BY) license (https:// creativecommons.org/licenses/by/ $4.0 /)$.

\begin{abstract}
Skin is constantly exposed to environmental insults, including toxic chemicals and oxidative stress. These insults often provoke perturbation of epidermal homeostasis and lead to characteristic skin diseases. AHR (aryl hydrocarbon receptor) and NRF2 (nuclear factor erythroid 2-related factor 2) are transcription factors that induce a battery of cytoprotective genes encoding detoxication and antioxidant enzymes in response to environmental insults. In addition to their basic functions as key regulators of xenobiotic and oxidant detoxification, recent investigations revealed that AHR and NRF2 also play critical roles in the maintenance of skin homeostasis. In fact, specific disruption of AHR function in the skin has been found to be associated with the pathogenesis of various skin diseases, most prevalently atopic dermatitis (AD). In this review, current knowledge on the roles that AHR and NRF2 play in epidermal homeostasis was summarized. Functional annotations of genetic variants, both regulatory and nonsynonymous SNPs, identified in the AHR and NRF2 loci in the human genome were also summarized. Finally, the possibility that AHR and NRF2 serve as therapeutic targets of AD was assessed.
\end{abstract}

Keywords: AHR; NRF2; atopic dermatitis; skin; detoxification; keratinocyte differentiation; air pollutants; SNPs

\section{Roles of AHR and NRF2 in Xenobiotic Detoxification}

Transcription factor AHR (aryl hydrocarbon receptor) is a ligand-activated transcription factor that belongs to a basic helix-loop-helix/PER-ARNT-SIM (bHLH-PAS) family [1]. AHR is activated by the binding of a large variety of exogenous ligands, which include environmental pollutants such as polycyclic aromatic hydrocarbons (PAHs) and dioxins (Figure 1a). In the absence of a ligand, AHR forms a complex in the cytoplasm with at least three factors: Heat shock protein 90 (HSP90), the cochaperone protein p23 and hepatitis $B$ virus $X$-associated protein 2 (XAP2) [2]. Upon binding of certain ligands to AHR, the AHR-HSP90-p23-XAP2 complex is disrupted, leading to the nuclear translocation of AHR. In the nucleus, AHR dimerizes with ARNT (AHR nuclear translocator) [3]. The AHRARNT heterodimer binds to XRE (xenobiotic response element) in regulatory regions of various AHR-target genes [4]. Prototype AHR-target genes include phase I detoxification enzymes such as cytochrome P450 (CYPs). Two AHR regulatory mechanisms have been reported. One is proteasomal degradation of the AHR protein, while the other is negative feedback regulation of AHR activation by the AHR repressor (AHRR) [5]. AHRR is known to be an AHR-target gene, and AHRR inhibits AHR activity by competing with AHR for dimerization with ARNT. 
a

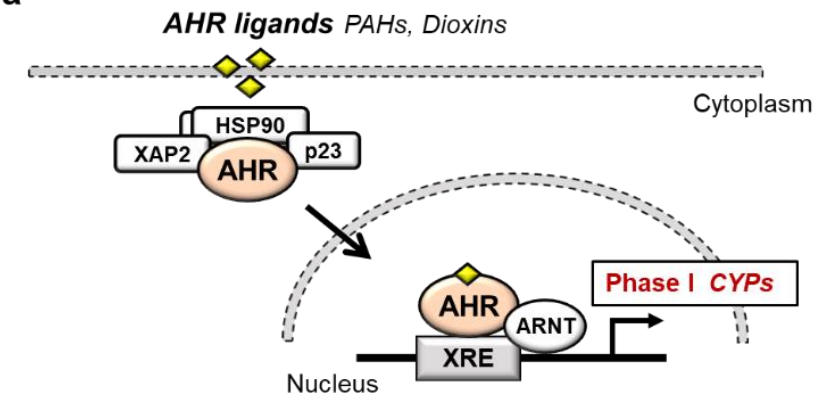

b

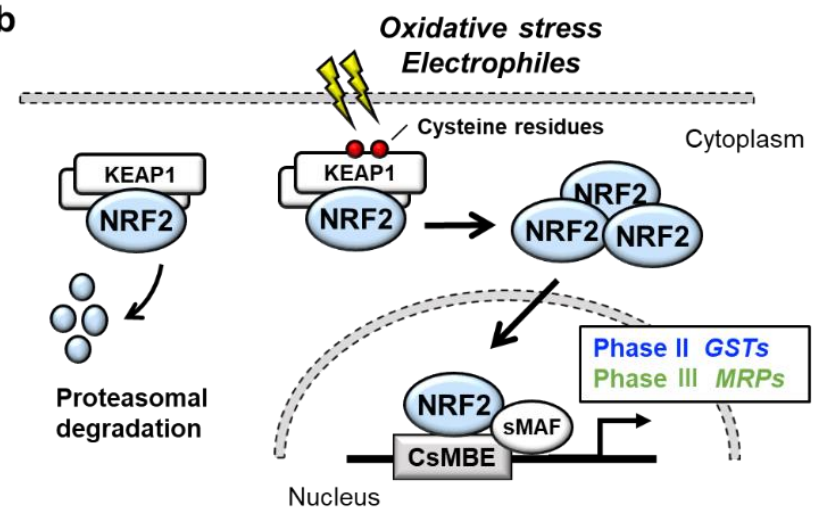

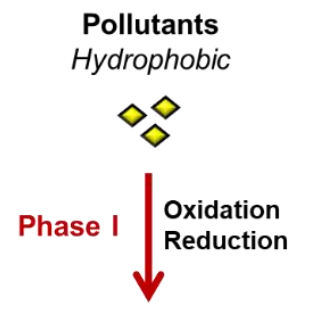

Intermediate metabolites

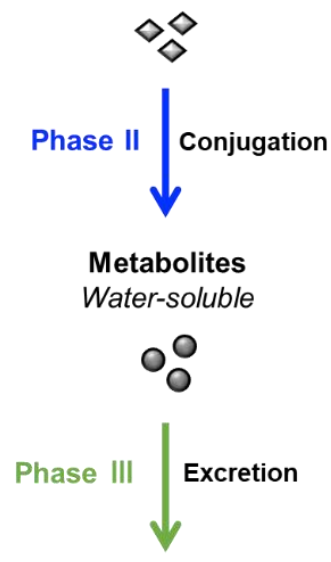

Figure 1. AHR and NRF2 in xenobiotic detoxification. (a) The AHR signaling pathway. In the absence of a ligand, AHR forms a complex with HSP90, p23 and XAP2 in the cytoplasm. Upon binding of ligands such as PAHs or dioxins, AHR translocates into the nucleus and forms a heterodimer with ARNT. The AHR-ARNT heterodimer binds to XRE in regulatory regions of target genes, which mainly encode phase I detoxification enzymes. (b) The KEAP1-NRF2 system. Under physiological conditions, KEAP1 binds and ubiquitinates NRF2 in the cytoplasm and promotes the degradation of NRF2 through the ubiquitin-proteasome pathway. Upon exposure to oxidative or electrophilic stresses, reactive cysteine residues of KEAP1 are modified, which leads to dysfunction of the ubiquitin ligase activity of KEAP1. Under this condition, newly made NRF2 escapes from KEAP1, translocates into the nucleus and forms a heterodimer with sMAF. The NRF2-sMAF heterodimer binds to CsMBE (also known as ARE or EpRE) in the regulatory regions of target genes, which mainly encode phase II detoxication enzymes and phase III transporters. (c) Xenobiotic detoxification. Xenobiotic detoxification consists of three phases. The phase I detoxication reaction involves oxidation or reduction of hydrophobic xenobiotics. The phase II detoxification reaction involves conjugation of the hydrophilic moiety by transferases to phase I metabolites, leading to the transformation of hydrophobic xenobiotics into water-soluble molecules. In the phase III reaction, the conjugated metabolites are eliminated from the cells through MRPs.

NRF2 (nuclear factor erythroid 2-related factor 2) is a transcription factor belonging to the cap'n'collar (CNC) family. NRF2 possesses a basic leucine zipper (bZIP) and a CNC structure. NRF2 induces a battery of cytoprotective genes in response to oxidative and electrophilic stresses [6,7]. Under physiological conditions, NRF2 is bound by the repressor protein KEAP1 (kelch-like ECH-associated protein 1) in the cytoplasm, which promotes NRF2 degradation by the ubiquitin-proteasome pathway (Figure 1b) [8,9]. Upon exposure to oxidative or electrophilic stresses, specific reactive cysteine residues of KEAP1 are modified, which leads to the disruption of the KEAP1-NRF2 interaction [10,11]. This stabilizes NRF2 so that NRF2 translocates to the nucleus and forms a heterodimer with small MAF (sMAF) protein. The NRF2-sMAF heterodimer complex binds to the CNC-sMAF binding element (CsMBE), which is also known as the antioxidant response element (ARE) or electrophile response element (EpRE), in the regulatory regions of target genes $[12,13]$. Closer examination of the NRF2-target genes revealed that a set of genes encoding phase II 
detoxification enzymes such as glutathione $S$-transferase (GSTs), antioxidative enzymes such as $\mathrm{NAD}(\mathrm{P}) \mathrm{H}$ :quinone oxidoreductase 1 (NQO1), glutamate-cysteine ligase catalytic subunit (GCLC) and phase III transporters such as multidrug-resistance-associated proteins (MRPs) in a member of ATP-binding cassette (ABC) transporters are the target genes of NRF2.

AHR and NRF2 are the key regulators of cytoprotective responses to environmental stresses. Both transcription factors play important roles in the transformation of hydrophobic molecules to water-soluble molecules that are easily eliminated from the body via urine, stool and sweat. Xenobiotic detoxification consists of three phases [14] (Figure 1c); the phase I detoxification reaction involves oxidation or reduction of xenobiotics, resulting in the conversion to more polar intermediate metabolites such as electrophiles. The phase II detoxification reaction involves conjugation of a hydrophilic moiety, e.g., glucuronate, sulfate, glutathione or glycine, to phase I metabolites. This reaction is catalyzed by a group of enzymes called transferases, and phase I metabolites are transformed into water-soluble molecules by transferases. In the phase III reaction, the conjugated metabolites are eliminated from the cells by transporters. It has been shown that AHR regulates the expression of phase I enzymes, such as CYP1A1, CYP1A2 and CYP1B1, while NRF2 regulates phase II enzymes, such as GSTA1, GSTP1 and UDP-glucuronosyl transferases (UGTs), and phase III transporters, such as MRPs.

\section{Crosstalk between AHR and NRF2}

The relationship between AHR and NRF2 has attracted attention, and a reciprocal relationship between AHR and NRF2 has been reported. First, Shin et al. showed that pharmacological activation of Nrf2 by CDDO-Im, 1-(2-cyano-3,12,28-trioxooleana-1,9(11)dien-28-yl)-1H-imidazole, induces $A h R$ mRNA and the mRNA expression of the target genes Cyp1a1 and Cyp1b1 in mouse embryonic fibroblasts (MEFs), indicating that Nrf2 directly regulates the transcription of $A h R$ mRNA (Figure 2a) [15]. The induction of the AhR, Cyp1a1 and Cyp1b1 genes was cancelled in Nrf2-knockout MEFs, and luciferase assays and chromatin immunoprecipitation (ChIP) assays showed that Nrf2 directly binds to a CsMBE at -230 of the $A h R$ promoter [15].

a

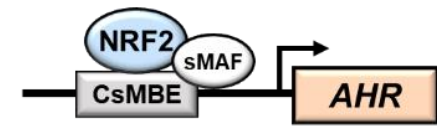

b

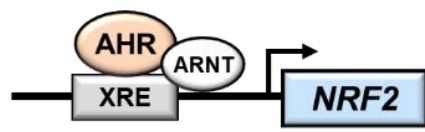

C

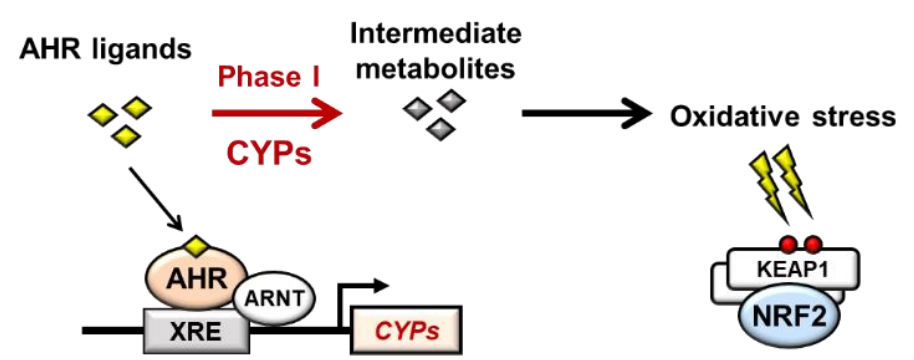

Figure 2. Interaction between AHR and NRF2. (a) Direct interaction between AHR and NRF2. NRF2 directly binds to a CsMBE in the $A H R$ promoter and increases the transcription of $A H R$ mRNA. (b) In contrast, AHR directly binds to an XRE in the NRF2 promoter and increases the transcription of NRF2 mRNA. (c) Indirect interaction between AHR and NRF2 through AHR-mediated oxidative stress. AHR ligands are metabolized by AHR-induced CYPs. Intermediate metabolites often induce oxidative stress, resulting in activation of NRF2.

In contrast, 2,3,7,8-tetrachlorodibenzo- $p$-dioxin (TCDD), a high affinity AhR ligand, was found to induce Nrf2 mRNA expression in an AhR-dependent manner in mouse 
hepatoma 1c1c7 cells, suggesting that AhR directly increased the transcription of Nrf2 mRNA (Figure 2b) [16]. Direct binding of AhR to the XRE-like elements at $-712,+755$ and +850 of the Nrf2 gene was confirmed by ChIP assay, and luciferase assay further revealed that TCDD induces Nrf2 gene expression through all three XRE-like elements [16]. In this regard, while it has been shown that NRF2 activation heavily depends on the stabilization of NRF2 protein from proteasome degradation $[8,9]$, there are reports that the transcriptional activation of NRF2 contributes to cellular NRF2 activity [17].

Therefore, it is interesting to note that in addition to the reports suggesting the direct relationship of AHR and NRF2, there are reports that suggest indirect interactions between AHR and NRF2 (Figure 2c). NRF2 is known to be activated by oxidative stresses, which are increased through the induction of CYPs. For instance, TCDD induces NQO1 gene expression in human hepatoma cell lines, but antioxidant $N$-acetyl cysteine (NAC) or CYP1A1 siRNA decreases NQO1 gene induction, indicating that NQO1 induction is controlled by CYP1A1 activity through oxidative stress [18]. TCDD activates Nrf2 activity in vivo in an AhR-dependent manner, leading to the induction of Nrf2 target genes, including Nqo1 and Gsta1, in mouse livers [19]. In contrast, Nrf2 target gene expression induced by TCDD could not be cancelled in the liver of Cyp1a1/1a2/1b1 triple-knockout mice, suggesting that AhR itself induces Nrf2 independent of Cyp enzyme activity [20]. Therefore, it appeared that AHR ligands directly or indirectly influence NRF2 activity, but further studies are needed to clarify the relationships between AHR activation and NRF2 induction.

\section{Barrier Function of the Skin}

The primary function of the skin is a surface barrier, which prevents dehydration and protects the body from environmental insults. Therefore, impairment of skin barrier function facilitates the absorption of environmental toxicants and leads to enhanced water loss. The skin consists of two layers, epidermis and dermis, and the epidermis includes four cell layers that mainly consist of keratinocytes (Figure 3a): The stratum corneum (SC), stratum granulosum (SG), stratum spinosum (SS) and stratum basale (SB).

a

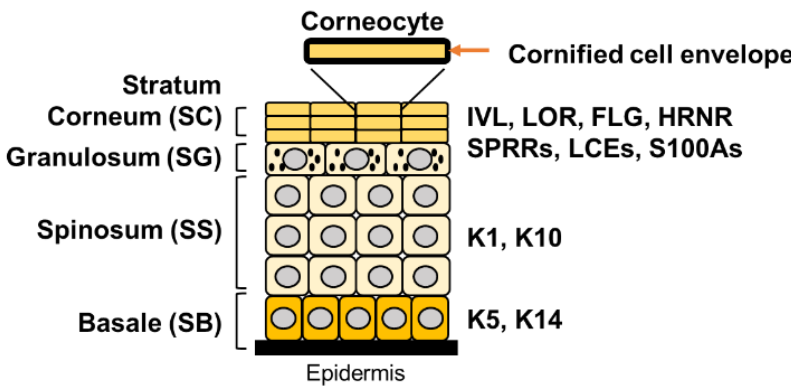

b

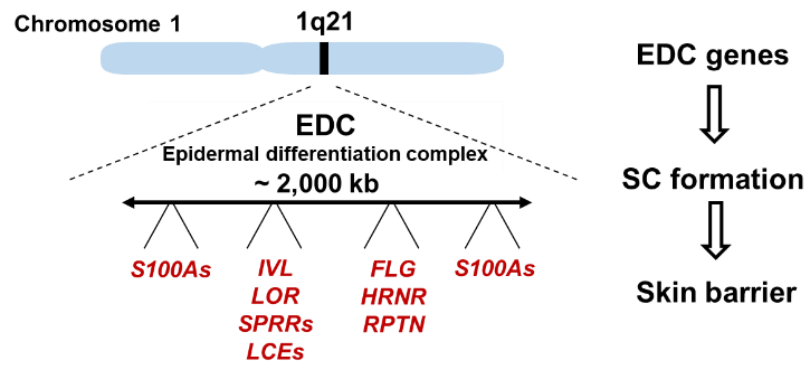

Figure 3. Structure of the epidermis and genes regulated by AHR and NRF2. (a) Structure of the epidermis. The epidermis includes four layers: SC, SG, SS and SB. Through cell migration from SB toward SC, keratinocytes start differentiation and sequentially express specific proteins, such as Keratin 5/14 at the SB stage and Keratin 1/10 at the SS stage. The outer layer SC consists of corneocytes, which are surrounded by a cornified cell envelope. SC expresses IVL, LOR, FLG, SPRRs, LCEs and the S100A family. (b) EDC on human chromosome 1q21. EDC genes encode the components of SC and function in the formation of the skin barrier. 
Barrier function of the skin mainly depends on SC, the outermost layer. SC consists of terminally differentiated keratinocytes, named corneocytes, which express involucrin (IVL), loricrin (LOR), filaggrin (FLG), small proline-rich proteins (SPRRs), late cornified envelope proteins (LCEs) and the S100A family. IVL, LOR, SPRRs and LCEs are the major components of the cornified cell envelope, a highly insoluble structure inside the plasma membrane of corneocytes. FLG is a complex mixture of water-soluble compounds such as amino acids, and is one of the major compounds of natural moisturizing factors in the epidermis. Most of the genes encoding the components of the cornified cell envelope are clustered in the epidermal differentiation complex (EDC) on human chromosome 1q21 (Figure 3b).

\section{Role of AHR in Epidermal Homeostasis}

A well-known function of AHR is the regulation of xenobiotic metabolism through the induction of CYPs. However, many lines of evidence have reported that ligand-activated AHR also acts to induce the expression of genes involved in skin barrier formation [21-24]. In fact, exposure of normal human epidermal keratinocytes to TCDD increases the mRNA expression of $40 \%(24 / 60)$ of the EDC genes involved in cornified cell envelope formation, such as FLG, FLG2, LCE1C, LCE2A, LCE2B, LCE3A, LCE3E, SPRR1A, SPRR2A, SPRR2B, S100A9, S100A12, S100A7, Repetin (RPTN) and Hornerin (HRNR) [23,24]. In organotypic cultures of human keratinocytes, treatment with TCDD causes well-developed SC, indicating that TCDD accelerates the onset of epidermal terminal differentiation [21]. Additionally, exposure to TCDD accelerates the formation of the fetal mouse skin barrier in utero [23]. Conversely, in primary keratinocytes derived from wild-type mice, the expression of terminal differentiation genes is suppressed by treatment with an AhR antagonist GNF351 or a selective AhR modulator SGA360 [25]. The expression of terminal differentiation genes is reproducibly repressed in AhR-knockout mouse primary keratinocytes [25]. These results support the physiological roles of AhR during epidermal differentiation.

AhR-knockout mice were generated in 1996-1997 independently in three distinct laboratories (Table 1) [26-28]. Fernandez-Salguero et al. reported an AhR-knockout mouse line generated by replacing a part of the first exon of the $A h R$ gene with a neomycin resistance cassette (NEO). The mice revealed severe hyperkeratosis, acanthosis and marked dermal fibrosis in the dorsal skin [26]. In contrast, the other two lines of AhR-knockout mice did not show characteristic skin phenotypes. The second and third knockout mouse lines were generated by the replacement of a part of the second exon with NEO and LacZ fused to a nuclear localization sequence, respectively $[27,28]$. While these differences in gene targeting strategy may contribute to the phenotypic difference of the skin, the precise reason for the phenotypic difference is currently unclear.

Consistent with the results of the latter two mouse lines, keratinocyte-specific AhRknockout mice using Keratin 14 (K14)-Cre (AhR ${ }^{\text {flox }:: K 14-C r e ~ m i c e) ~ s h o w ~ n o ~ o b v i o u s ~ m a c r o-~}$ scopic phenotypes in unstressed skin [29]. However, when the upper layers of SC are mechanically removed by tape stripping, transepidermal water loss (TEWL) values in $\mathrm{AhR}^{\text {flox }: \mathrm{K} 14-C r e}$ mice are substantially increased compared with those in control mice, suggesting that AhR plays a role in skin barrier function [29]. These studies using AhRknockout cell lines and AhR-knockout mice support the notion that AHR is involved in epidermal homeostasis $[25,26]$, although there remain many unsolved questions.

ARNT is indispensable for the transcriptional activity of AHR. Keratinocyte-specific Arnt-knockout mice using Keratin 5 (K5)-Cre (Arnt flox::K5-Cre mice) show severe impairment of the epidermal barrier [30]. Arnt flox::K5-Cre mice exhibit a loss of body weight and die within $24 \mathrm{~h}$ after birth [30]. TEWL is increased in the epidermis of Arnt flox::K5-Cre mice, and the application of salve to the skin retards weight loss; the mice survive longer than $24 \mathrm{~h} \mathrm{[30].} \mathrm{These} \mathrm{observations} \mathrm{indicate} \mathrm{that} \mathrm{skin} \mathrm{barrier} \mathrm{dysfunction} \mathrm{results} \mathrm{in} \mathrm{severe}$ dehydration in Arnt flox::K5-Cre mice. 
Table 1. Genetically modified mouse models targeting AhR/Arnt and Keap1/Nrf2.

\begin{tabular}{|c|c|c|c|c|}
\hline Mouse & \multicolumn{3}{|c|}{ Reference } & Main Skin Phenotype \\
\hline \multicolumn{5}{|l|}{ AhR } \\
\hline \multirow{3}{*}{ AhR-knockout } & Schmidt et al. & 1996 & [28] & \multirow{2}{*}{ No obvious phenotypes in normal condition } \\
\hline & Mimura et al. & 1997 & [27] & \\
\hline & Fernandez-Salguero et al. & 1997 & [26] & Hyperkeratosis, acanthosis and dermal fibrosis \\
\hline 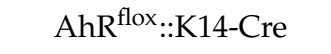 & Haas et al. & 2016 & [29] & Increased TEWL after tape stripping \\
\hline AhR-CA & Tauchi et al. & 2005 & $\begin{array}{l}{[31]} \\
{[32]}\end{array}$ & $\begin{array}{l}\text { Hyperkeratosis, acanthosis and dermal infiltration } \\
\text { with inflammatory cellsFrequent scratching behavior }\end{array}$ \\
\hline \multicolumn{5}{|l|}{ Arnt } \\
\hline Arnt ${ }^{\text {flox::K14-Cre }}$ & Takagi et al. & 2003 & [30] & \multirow{2}{*}{ Increased TEWL and postnatal death } \\
\hline Arnt $^{\text {flox }:: K 5-C r e ~}$ & Geng et al. & 2006 & [33] & \\
\hline \multicolumn{5}{|l|}{ Keap1 } \\
\hline \multirow[b]{2}{*}{ Keap1-knockout } & \multirow[b]{2}{*}{ Wakabayashi et al. } & \multirow[b]{2}{*}{2003} & \multirow[b]{2}{*}[34]{} & Hyperkeratosis \\
\hline & & & & $\begin{array}{l}\text { Death before weaning age due to obstruction of the } \\
\text { esophagus and forestomach }\end{array}$ \\
\hline \multicolumn{5}{|l|}{ Nrf2 } \\
\hline caNrf2::K5-Cre & Schäfer et al. & $\begin{array}{l}2012 \\
2014\end{array}$ & $\begin{array}{l}{[35]} \\
{[36]}\end{array}$ & $\begin{array}{l}\text { Hyperkeratosis, acanthosis, cyst formation } \\
\text { andenlarged sebaceous glands }\end{array}$ \\
\hline Lor-knockout::dnNrf2 & Huebner et al. & 2012 & [37] & Failure in skin barrier formation and postnatal death \\
\hline
\end{tabular}

Consistent with the results of the Arnt flox::K5-Cre mice, keratinocyte-specific Arnt-

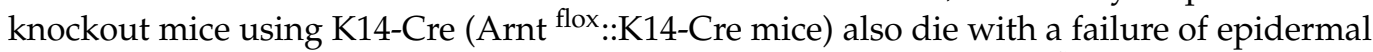
barrier function [33]. Microarray analyses of the epidermis of Arnt flox::K14-Cre mice revealed upregulation of several EDC genes, including S100a genes (S100a8, S100a9, S100a10) and Sprrs (Sprr1a, Sprr2i, Sprr2j, Sprrl1) [33]. Furthermore, serine protease inhibitors, including secretory leukocyte protease inhibitor (Slpi), are also upregulated and are involved in SC desquamation [33]. While Hif1 $\alpha$ (hypoxia-inducible factor $1 \alpha$ ) can also form a heterodimer with Arnt, keratinocyte-specific Hif1 $\alpha$-knockout mice using K5-Cre (Hif1 $\alpha^{\text {flox::K5-Cre mice) }}$ show no obvious phenotype, suggesting that the AhR-Arnt heterodimer rather than Hif1 $\alpha$ Arnt is responsible for epidermal homeostasis [30]. These wide-ranging reports suggest that AhR or Arnt deficiency impairs the development and function of the epidermal barrier, but further clarifications are required to understand the general features.

\section{Role of NRF2 in Epidermal Homeostasis}

Nrf2 is involved in the regulation of epidermal homeostasis, and analyses of several genetically modified mice support this notion (Table 1). Systemic Keap1-knockout mice in which Nrf2 activity is constitutively activated macroscopically exhibit scaling skin, and histological examinations reveal the presence of severe hyperkeratosis in the skin, esophagus and forestomach [34]. Keap1-knockout mice die before weaning due to obstruction of the esophagus and forestomach caused by hyperkeratosis of the squamous cell epithelium [34]. As epithelial dysfunction can be rescued by concomitant Nrf2 gene deletion, high-level activation of Nrf2 in keratinocytes caused by Keap1 deletion must be the reason for epithelial abnormalities [34].

Showing very good agreement with the results of Keap1-knockout mice, a transgenic mouse line expressing a constitutively active Nrf2 mutant (caNrf2) specifically in keratinocytes was shown to display scaling and dry skin [35]. caNrf2 lacks the Neh2 domain, which is responsible for binding to Keap1, and this molecule is expressed under the control of a strong CMV enhancer and specific removal of the stopper cassette by K5Cre (caNrf2::K5-Cre mouse). Histological analyses of the caNrf2 transgenic mice showed 
thickening of the epithelium (acanthosis) and severe hyperkeratosis in the skin. Microarray analyses using the skin of caNrf2::K5-Cre mice at postnatal Day 2.5 revealed upregulation of genes involved in epidermal barrier formation, including Slpi, Sprr2d and Sprr2h [35]. These mouse phenotypes suggest that prolonged activation of Nrf2 in keratinocytes disturbs skin homeostasis.

Supporting this notion, this research group has also reported that Nrf2 activation in newborn mice induced by topical application with sulforaphane or tert-butyl hydroquinone (tBHQ) for 10 days also causes skin abnormalities resembling those of caNrf2::K5-Cre mice [35]. However, the concentrations of the inducers applied were $10 \mathrm{mM}$ and $50 \mathrm{mM}$ for sulforaphane and $\mathrm{tBHQ}$, respectively, which are very high doses. Therefore, the relationship between pharmacological induction of skin phenotypes and Nrf2 contribution awaits further verification.

In this regard, crossing a transgenic mouse line expressing the dominant-negative form of Nrf2 (dnNrf2) under the control of the Lor promoter to Lor-knockout mice (Lorknockout::dnNrf2 mice) showed a distinct phenotype. Inhibition of endogenous Nrf2 activity by dnNrf2 in the Lor-deficient epidermis causes severe loss of barrier function and death within $24 \mathrm{~h}$ [37]. LOR is the main component of the cornified cell envelope. While Lor-knockout mice show a delay in the formation of the epidermal barrier in utero, the mice can survive with the formation of a functional barrier by birth [38]. Other cornified cell envelope components, including Sprrs and Lce1, are upregulated in the epidermis of Lorknockout mice, so they might compensate for the loss of Lor [38,39]. In fact, the expression of Sprrs and Lce1 genes is decreased to basal levels in the epidermis of Lor-knockout::dnNrf2 mice $[37,39]$. ChIP assays and reporter assays show that Nrf2 directly upregulates the Sprrs (Sprr2d and Sprr2h) and Lce1 genes (Lce1b, Lce1c, Lce1e, Lce1g, Lce1h and Lce1m) [37,39]. These results suggest that Nrf2 activation in Lor-knockout mice may act to induce a compensatory response to repair the defective barrier. While the Keap1-Nrf2 system is generally the major cellular protection mechanism against xenobiotic and oxidative stresses, these reports suggest that Nrf2 plays important roles in the maintenance of skin homeostasis, similar to AhR.

\section{AHR as Therapeutic Target for Atopic Dermatitis}

Atopic dermatitis (AD) is a chronic recurrent inflammatory skin disease characterized by epidermal barrier dysfunction and immune dysregulation. Loss-of-function variants in FLG, which is essential for the formation of the epidermal barrier, have been reported to be the most common risk factor for the development of AD [40]. However, only $40 \%$ of individuals with FLG variations develop AD symptoms [40-42]. These facts indicate that other factors are also involved in the pathogenesis of $\operatorname{AD}[42,43]$.

It has been shown that AD patients account for up to $25 \%$ of children and $2-3 \%$ of adults [44]. Of note, the international study of asthma and allergies in childhood (ISAAC), which is a worldwide epidemiological research in more than 50 countries, revealed that the prevalence of AD increased among schoolchildren between ISAAC phase I (1992-1996) and phase III (2000-2003) studies in many parts of the world [45]. In addition, a systematic review including 69 reports showed that the prevalence of AD between 1990 and 2010 increased in Africa, East Asia and parts of Europe [46]. While the pathophysiology of $\mathrm{AD}$ appears to be multifactorial with complex interactions between genetic and environmental factors, the recent increase in the prevalence of AD supports the attribution of environmental factors in predisposed individuals [47].

In fact, several lines of epidemiological research provide evidence that exposure of the skin to air pollutants acts as a risk factor for the development or aggravation of AD (Table 2). Outdoor air pollutants are mostly generated from the burning of fossil fuels for vehicles and industries [48], and components of air pollutants mainly include particulate matter (PM), which is a mixture of solid or liquid particles suspended in the air. Outdoor concentrations of PM are associated with increased AD symptoms and itching [49,50]. A meta-analysis of 13 studies showed positive correlations between PM exposure and AD [51]. 
Importantly, PM contains PAHs, prototypical AHR ligands, and induces CYP1A1 mRNA expression in an AHR-dependent manner in human primary keratinocytes [52]. In addition to PM, active smoking and passive exposure to tobacco in the home are also associated with a higher prevalence of AD in both children and adults [53]. Tobacco smoke is the major source of indoor pollutants and contains numerous chemical constituents, including PAHs [54]. These reports support the hypothesis that AHR activation is involved in AD caused by air pollutants.

Table 2. Effects of air pollutants on the risk of atopic dermatitis (meta-analysis).

\begin{tabular}{cccccc}
\hline \multicolumn{2}{c}{ Pollutants } & $\begin{array}{c}\text { Odds Ratio } \\
\text { (95\% CI) }\end{array}$ & \multicolumn{3}{c}{ Reference } \\
\hline \multirow{3}{*}{ Tobacco smoke } & Active smoking & $1.87(1.32-2.63)$ & Kantor et al. & 2016 & {$[55]$} \\
PM2.5 & Passive smoking & $1.18(1.01-1.38)$ & Ng et al. & 2020 & {$[56]$} \\
& Maternal smoking & $2.95(2.43-3.60)$ & Ngoc et al. & 2017 & {$[51]$} \\
\hline
\end{tabular}

A model study employing constitutively active AhR in mice supported the hypothesis that AhR plays an important role in the development of AD [31]. To analyze the effects of chronic AhR activation in the epidermis, a transgenic mouse expressing a constitutively active form of AhR was generated under the control of the K14 promoter (AhR-CA mice; Table 1). AhR-CA mice develop erosive eczema in the face and back skin with highly frequent scratching [31]. Histological examination shows acanthosis, hyperkeratosis and abundant infiltration of cells related to Th2-type inflammation in the skin [32]. These phenotypes highly recapitulate those of patients with $\mathrm{AD}$, indicating that the constitutive activation of AhR provokes pathological conditions similar to those frequently observed in patients with AD.

Notably, in the epidermis of AhR-CA mice, the neurotrophic factor Artemin is highly expressed, which causes extension of sensory nerves into the epidermis and provokes hypersensitivity to itch or alloknesis [32,57]. The Artemin gene is directly regulated by AhR via an XRE-containing enhancer located $52 \mathrm{~kb}$ upstream of the gene [58]. Showing very good agreement with these results, in the skin of AD patients, AHR is activated, followed by upregulation of the mRNA and protein levels of CYP1A1 and ARTEMIN [32,59].

In contrast, it has been reported that AHR activation improves skin barrier function by accelerating epidermal terminal differentiation. For instance, coal tar has been used as a therapeutic agent for inflammatory skin diseases, including AD. In fact, topical application of coal tar restores the expression of skin barrier proteins, including FLG, in the skin of patients with AD [60]. Coal tar contains abundant PAHs and has been shown to induce epidermal differentiation via AHR. The efficacy of coal tar seems to be attributable to AHR activation [60].

In addition, tapinarof, 3,5-dihydroxy-4-isopropyl-trans-stilbene, a natural origin small molecule, shows efficacy in patients with AD and is now in clinical development for the treatment of skin diseases. In a phase 2 double-blind study, AD symptom was improved in the patients treated with tapinarof cream [61,62]. Recent research revealed that tapinarof activates AHR through direct binding as an agonist and induces mRNA expression of epidermal terminal differentiation markers, including FLG and IVL, in primary human keratinocytes [63]. Imiquimod has been used to provoke skin inflammation that mimics psoriasis, and tapinarof reduces imiquimod-induced inflammation in mouse skin in an AhRdependent manner [63]. Similar to the case for coal tar, the efficacy of tapinarof is considered to depend, at least partially, on the AhR activity. These wide-ranging observations thus demonstrate that AHR activation acts to repair skin barrier function, but in turn, excessive expression of AHR leads to the development of AD (Figure 4). These reports demonstrated that AHR is a potential therapeutic target, and moderate-level activation of AhR may have therapeutic efficacy for skin barrier recovery. In contrast, AHR inhibitors seem to be important for the treatment of AD. 


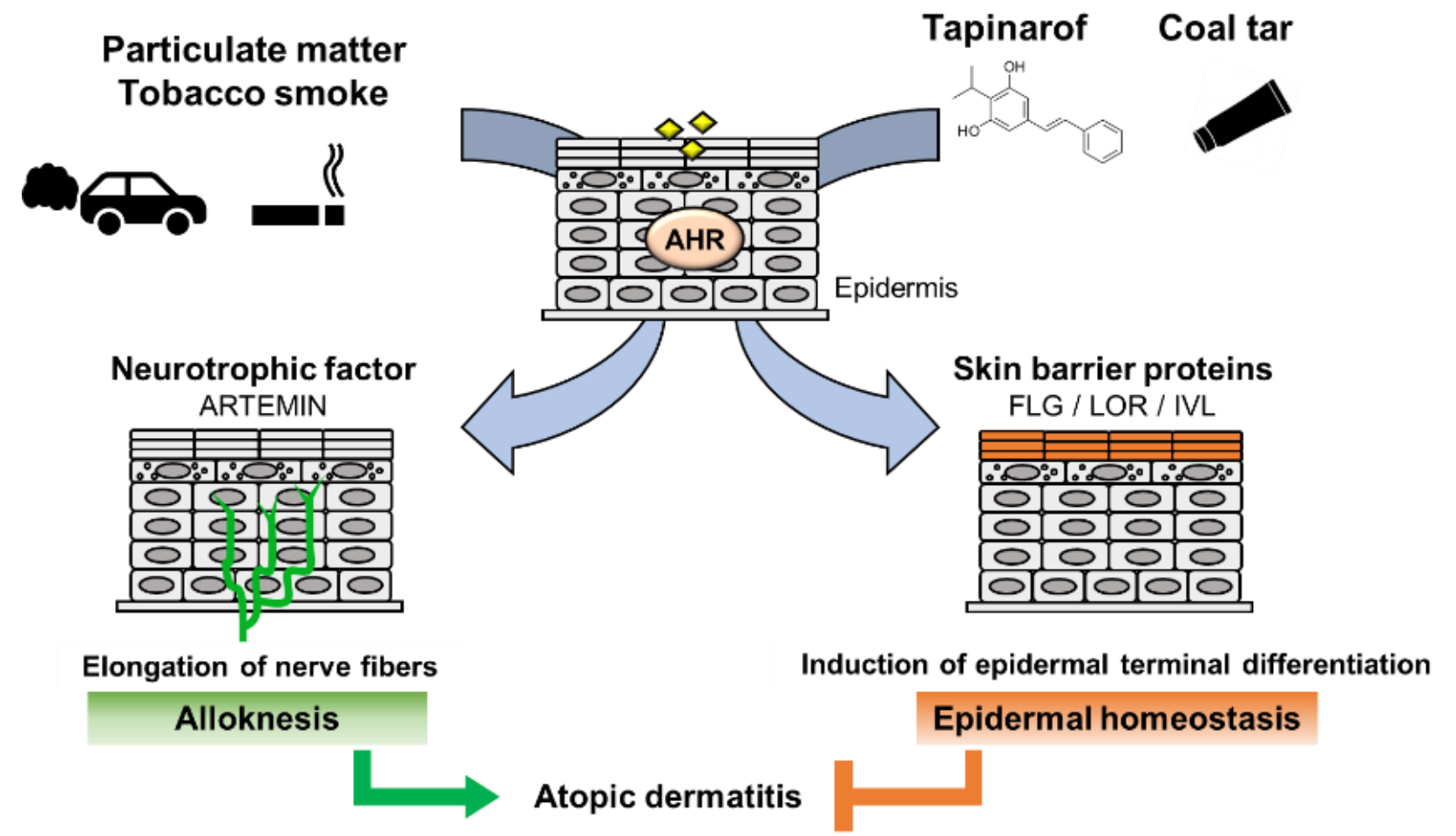

Figure 4. Dual functions of AHR in atopic dermatitis. PM and tobacco smoke contain PAHs that activate AHR. Activation of AHR induces the expression of the neurotrophic factor Artemin. Upregulation of Artemin causes extension of cutaneous sensory nerves into the epidermis and provokes hypersensitivity to itch or alloknesis. Tapinarof and coal tar improve skin barrier function by accelerating epidermal terminal differentiation.

\section{Genetic Factors Affecting the NRF2 Activities}

The human NRF2 gene is located on chromosome 2q31.2, and according to the single nucleotide polymorphism database (dbSNP), there are multiple SNPs in the NRF2 locus. One salient example is a regulatory SNP (rSNP) -617 C>A (rs6721961), which is in the ARE-like motif in the upstream promoter region of the NRF2 gene (Figure 5a). The minor allele frequency (MAF) of NRF2 - 617 C > A varies among populations and is relatively high in Asians; the MAF is 0.07 in Africans, 0.21 in Asians and 0.12 in Europeans according to the dbSNP. In fact, the frequency is also high in the Japanese population, but it varies depending on the research: 0.25 in jMorp 14KJPN (Japanese multi-omics reference panel) and 0.28 in the Iwaki health promotion project $[64,65]$.

It has been shown that the luciferase activity of a promoter construct with the $-617 \mathrm{~A} / \mathrm{A}$ variant is lower than that of a construct bearing the $-617 \mathrm{C} / \mathrm{C}$ variant when transfected into A549 cells [66]. Electrophoretic mobility shift assay (EMSA) has shown that the formation of NRF2 protein-DNA complex in the ARE-like sequence is reduced in the C/A and A/A genotypes compared with the $\mathrm{C} / \mathrm{C}$ genotypes, indicating that the rSNP $-617 \mathrm{C}>\mathrm{A}$ decreases the affinity of NRF2 binding to the ARE-like motif, resulting reduced self-induction of NRF2 [66]. Supporting this notion, the minor A/A genotype at -617 exhibits a lower level of NRF2 mRNA expression in human lymphocytes by approximately $40 \%$ than the $\mathrm{C} / \mathrm{C}$ and $\mathrm{C} / \mathrm{A}$ genotypes [17]. The expression levels of $\mathrm{tBHQ}$-induced NRF2 protein and NQO1 mRNA in A/A genotypes were lower than those in C/C genotype lymphocytes [17]. It has been shown that the rSNP at $-617 \mathrm{C}>\mathrm{A}$ is associated with a higher risk of various oxidative stress-involved diseases, including acute lung injury [66], non-small-cell lung cancer in smokers [17], noise-induced hearing loss [67], venous thromboembolism [68] and vascular stiffness with aging [64]. 
a

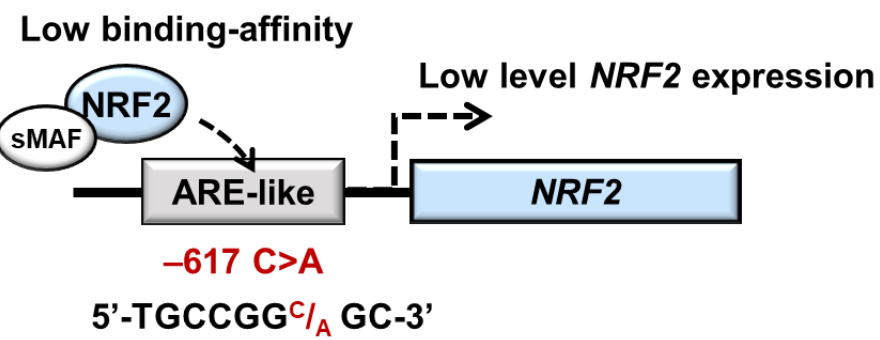

b

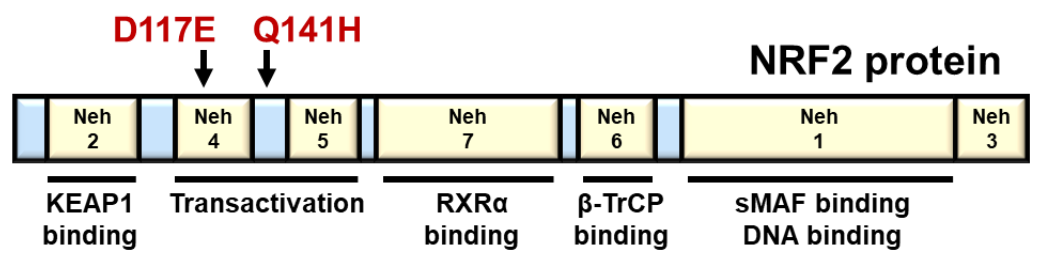

Figure 5. A regulatory SNP and two nonsynonymous SNPs in the NRF2 gene. (a) Location of NRF2 rSNP-617 in the ARE-like motif in the upstream promoter region of the NRF2 gene. rSNP - 617 C >A decreases the affinity of NRF2 binding to the ARE-like motif. (b) Location of nonsynonymous NRF2 SNPs associated with NRF2 domain structures. Human NRF2 protein contains 7 Neh domains. Neh, Nrf2-ECH homology.

In addition to the rSNP at $-617 \mathrm{C}>\mathrm{A}$, many nonsynonymous SNPs are found and reported in the coding region of the human NRF2 gene [69-71]. Of the nonsynonymous SNPs, the following two are interesting to note (Figure 5b). D117E (351 T>A, rs1469602964) and Q141H (423 G>T, undetermined rs number) variants of NRF2 were found to enfeeble NRF2 activity in an experiment utilizing 293T culture cells [71]. Furthermore, the mRNA levels of NRF2 target genes, including GSTP1, GSTM1 and heme oxygenase-1 (HO-1), are reduced in D117E- and Q141H-expressing 293T cells compared with cells expressing wildtype NRF2, and these NRF2 variants are proposed to be associated with the pathogenesis of Parkinson's disease in Chinese populations [71]. These are intriguing observations suggesting the roles that NRF2 plays in neuroinflammatory diseases but need to be verified further in successive cohort studies.

While there is no report on the relationship of the NRF2 SNPs with AD pathogenesis, the polymorphisms of GSTM1 and GSTT1, which are members of the GST gene family and NRF2 target genes, are reported to increase the risk of AD [72].

\section{Genetic Factors Affecting the AHR Activity}

The human $A H R$ gene is located on chromosome 7p15, and many genetic polymorphisms have also been reported in the human $A H R$ gene. Of the many genetic polymorphisms in the coding region of the human $A H R$ gene, three nonsynonymous mutations were characterized in detail (Figure 6a). The most common SNP in this gene is the $1661 \mathrm{G}>\mathrm{A}$ (rs2066853) missense mutation, which causes an arginine to lysine substitution at codon 554 (R554K) [73], which resides in the transactivation domain of AHR. The MAF of AHR R554K varies depending on the ethnic background: 0.45 in Africans, 0.34 in Asians and 0.10 in Europeans according to the dbSNP.

It has been shown that this AHR variant is associated with a higher risk of diseases in Asia. In fact, incidences of vitiligo in Chinese [74], lung cancer among cigarette smokers in Chinese [75], coronary arterial disease in Chinese [76] and breast cancer in Thailand [77] are increased in the populations harboring these variants, suggesting that the R554K polymorphism affects the inducibility of AHR target genes and influences the onset or progression of human diseases. 
a

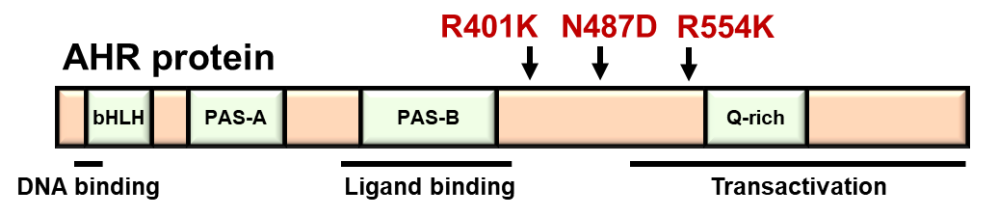

b

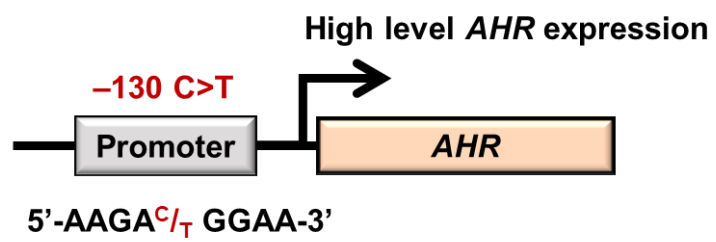

Figure 6. Three nonsynonymous SNPs and one regulatory SNP in the AHR gene. (a) Location of three nonsynonymous AHR SNPs associated with AHR domain structures. Human AhR protein contains several functional domains. bHLH, basic helix-loop-helix; PAS, P-ARNT-S; Q-rich, glutamine rich. (b) Location of rSNP-130 in the AHR gene. This rSNP has been shown to increase transcriptional regulation of the $A H R$ gene.

However, it remains controversial whether the AHR R554K polymorphism has a positive or negative effect on AHR activity. Smart et al. reported that when induced by 3-methylcholanthrene (3-MC) in human lymphocytes, the AHR R554K variant increases the CYP1A1 mRNA level higher than that in wild-type lymphocytes [78]. In contrast, Koyano et al. reported that the variant does not alter the AHR mRNA and AHR protein levels in HeLa cells [79]. Wong et al. showed that CYP1A1 mRNA expression levels did not change substantially between murine hepatoma Hepa-1 cells transfected with human AHR R554K and wild-type AHR when induced with TCDD [80]. These results suggest that the molecular mechanism by which the R554K variant acts awaits further investigation. We speculate that the influence of R554K substitution may be context dependent.

A couple of nonsynonymous SNPs in the AHR gene resulting in K401R (1202 A>G, undetermined rs number) and N487D (1459 $A>G$, rs75519181) substitutions have also been reported with MAF 0.01 and 0.002 in the Japanese population, respectively $[73,79]$. Because both AHR variant proteins are easily degraded through the proteasome pathway, the expression levels of these mutant AHR proteins are reduced to approximately half of the wild-type AHR level in HeLa cells [79]. Furthermore, when the expression of the CYP1A1-based luciferase reporter was induced by cotransfection of AHR mutant K401R or N487D along with $\beta$-naphthoflavone (BNF)- or 3-MC-treatment, the expression levels of luciferase reporter activity were reduced to approximately half of those induced by wild-type AHR. One plausible explanation for the latter observation is that ligand binding makes these mutant AHR proteins further unstable [81]. The phenotypic consequences of both variants are not available at present.

In addition to the SNPs within the coding region of the $A H R$ gene, a rSNP at $-130 \mathrm{C}>\mathrm{T}$ (rs10249788) has also been reported in the AHR upstream promoter region (Figure 6b). The ethnicity of this rSNP has been reported [82]; the MAF of $-130 \mathrm{C}>\mathrm{T}$ is 0.01 in Africans, 0.14 in Asians and 0.01 in Europeans, based on the dbSNP. This rSNP has been shown to affect transcriptional regulation of the AHR gene [83]. AHR mRNA, AHR protein and TCDD-induced CYP1A1 mRNA levels in the minor T/T genotype are higher than those in the $\mathrm{C} / \mathrm{C}$ genotype in normal human chorionic stromal cells [83]. Intriguingly, it has been reported that Chinese AD patients with both 1661G >A (R554K) and -130 C > T SNPs in combination show a higher risk of severe dry skin, suggesting that both SNPs may affect the formation of the skin barrier [84]. The influences of these SNPs are expected to be clarified in a much deeper layer. 


\section{Conclusions}

Both the AHR system and the NRF2 system function as sensor-effector machineries connecting external signals to internal cellular responses. Both systems act against environmental stresses in various tissues, including the skin. Recent advances in functional dissections have revealed that the AHR and NRF2 systems are involved in the maintenance of epidermal homeostasis, in addition to the well-known roles both systems play in detoxification. In this review, we have described recent knowledge about AHR and NRF2 involvement in susceptibility to environmental stresses and the pathogenesis of AD.

Clinical phenotypes of AD are heterogeneous $[85,86]$. AD is also known as a multifactorial skin disease resulting from complex interactions between genetic and environmental factors. Intense pruritus is a common symptom of AD that impairs quality of life including sleep [87]. However, we do not have curative therapies for AD. Reducing skin inflammation and pruritis is a primary goal of treatment. In this regard, large-scale cohorts and biobanks have been established that enable the utilization of human specimens and integrated data from cohort studies [88]. We expect that in the near future research aiming to identify specific populations that are more susceptible to environmental stress will emerge, and through such studies, we can challenge a comprehensive understanding of the pathogenesis of AD. While the current standard treatments of AD do not focus on the individual pathogenesis mechanisms of $\mathrm{AD}$, we will be able to develop targeted and personalized medicine for AD.

Author Contributions: T.E., K.T., R.O. and M.Y.: writing-original draft preparation, review and editing. All authors have read and agreed to the published version of the manuscript.

Funding: This work was supported by funding from AMED-FORCE [21gm4010015h0001 (M.Y. and R.O.)], MEXT/JSPS KAKENHI [19H05649 (M.Y.), 19K07395 (K.T.), $17 H 04240$ (R.O.)], and AMED-PCREATE [JP20cm0106101 (M.Y.)].

Conflicts of Interest: The authors declare no conflict of interest.

\section{Abbreviations}

$\begin{array}{ll}\text { ABC } & \text { ATP-binding cassette } \\ \text { AD } & \text { atopic dermatitis } \\ \text { AHR } & \text { aryl hydrocarbon receptor } \\ \text { AHRR } & \text { aryl hydrocarbon receptor repressor } \\ \text { ARE } & \text { antioxidant response element } \\ \text { ARNT } & \text { aryl hydrocarbon receptor nuclear translocator } \\ \text { BNF } & \beta \text {-naphthoflavone } \\ \text { bHLH-PAS } & \text { basic helix-loop-helix/PER-ARNT-SIM } \\ \text { bZIP } & \text { basic leucine zipper } \\ \text { caNrf2 } & \text { constitutively active Nrf2 mutant } \\ \text { CDDO-Im } & \text { 1-(2-cyano-3,12,28-trioxooleana-1,9(11)-dien-28-yl)-1H-imidazole } \\ \text { ChIP } & \text { chromatin immunoprecipitation } \\ \text { CNC } & \text { cap'n'collar } \\ \text { CsMBE } & \text { CNC-sMAF binding element } \\ \text { CYP } & \text { cytochrome P450 } \\ \text { dbSNP } & \text { the single nucleotide polymorphism database } \\ \text { dnNrf2 } & \text { dominant-negative form of Nrf2 } \\ \text { EDC } & \text { epidermal differentiation complex } \\ \text { EGF } & \text { epidermal growth factor } \\ \text { EMSA } & \text { electrophoretic mobility shift assay } \\ \text { EpRE } & \text { electrophile response element } \\ \text { FLG } & \text { filaggrin } \\ \text { GCLC } & \text { glutamate-cysteine ligase catalytic subunit } \\ \text { GST } & \text { glutathione } S \text {-transferase } \\ \text { Hif1 } \alpha & \text { hypoxia-inducible factor } 1 \alpha\end{array}$




\begin{tabular}{|c|c|}
\hline $\mathrm{HO}-1$ & heme oxygenase- 1 \\
\hline HRNR & hornerin \\
\hline HSP90 & heat shock protein 90 \\
\hline ISAAC & the international study of asthma and allergies in childhood \\
\hline IVL & involucrin \\
\hline jMorp & Japanese multi-omics reference panel \\
\hline K5 & keratin 5 \\
\hline K14 & keratin 14 \\
\hline KEAP1 & kelch-like ECH-associated protein 1 \\
\hline LCE & late cornified envelope protein \\
\hline LOR & loricrin \\
\hline MAF & minor allele frequency \\
\hline 3-MC & 3-methylcholanthrene \\
\hline MEF & mouse embryonic fibroblast \\
\hline MRP & multidrug-resistance-associated protein \\
\hline NAC & $N$-acetyl cysteine \\
\hline $\mathrm{NEO}$ & neomycin resistance cassette \\
\hline NQO1 & NAD(P)H:quinone oxidoreductase 1 \\
\hline NRF2 & nuclear factor erythroid 2-related factor 2 \\
\hline PCB & polychlorinated biphenyl \\
\hline PM & particulate matter \\
\hline RPTN & repetin \\
\hline rSNP & regulatory single nucleotide polymorphism \\
\hline SB & stratum basale \\
\hline SC & stratum corneum \\
\hline SG & stratum granulosum \\
\hline Slpi & secretory leukocyte protease inhibitor \\
\hline sMAF & small musculoaponeurotic fibrosarcoma \\
\hline SNP & single nucleotide polymorphism \\
\hline SPRR & small proline-rich protein \\
\hline SS & stratum spinosum \\
\hline $\mathrm{tBHQ}$ & tert-butyl hydroquinone \\
\hline TCDD & 2,3,7,8-tetrachlorodibenzo- $p$-dioxin \\
\hline TEWL & transepidermal water loss \\
\hline UDP & uridine diphosphate \\
\hline UGT & uridine diphosphate -glucuronosyl transferase \\
\hline XAP2 & hepatitis B virus $X$-associated protein 2 \\
\hline XRE & xenobiotic response element \\
\hline
\end{tabular}

\section{References}

1. Ema, M.; Sogawa, K.; Watanabe, N.; Chujoh, Y.; Matsushita, N.; Gotoh, O.; Funae, Y.; Fujii-Kuriyama, Y. cDNA cloning and structure of mouse putative Ah receptor. Biochem. Biophys. Res. Commun. 1992, 184, 246-253. [CrossRef]

2. Petrulis, J.R.; Perdew, G.H. The role of chaperone proteins in the aryl hydrocarbon receptor core complex. Chem. Biol. Interact. 2002, 20, 25-40. [CrossRef]

3. Reyes, H.; Reisz-Porszasz, S.; Hankinson, O. Identification of the ah receptor nuclear translocator protein (arnt) as a component of the DNA binding form of the ah receptor. Science 1992, 256, 1193-1195. [CrossRef] [PubMed]

4. Fujisawa-Sehara, A.; Yamane, M.; Fujii-Kuriyama, Y. A DNA-binding factor specific for xenobiotic responsive elements of P-450c gene exists as a cryptic form in cytoplasm: Its possible translocation to nucleus. Proc. Natl. Acad. Sci. USA 1988, 85, 5859-5863. [CrossRef]

5. Fujii-Kuriyama, Y.; Kawajiri, K. Molecular mechanisms of the physiological functions of the aryl hydrocarbon (dioxin) receptor, a multifunctional regulator that senses and responds to environmental stimuli. Proc. Jpn. Acad. Ser. B Phys. Biol. Sci. 2010, 86, 40-53. [CrossRef]

6. Yamamoto, M.; Kensler, T.W.; Motohashi, H. The KEAP1-NRF2 system: A thiol-based sensor-effector apparatus for maintaining redox homeostasis. Physiol. Rev. 2018, 98, 1169-1203. [CrossRef]

7. Taguchi, K.; Yamamoto, M. The KEAP1-NRF2 system as a molecular target of cancer treatment. Cancers 2020, 13, 46. [CrossRef]

8. Itoh, K.; Wakabayashi, N.; Katoh, Y.; Ishii, T.; Igarashi, K.; Engel, J.D.; Yamamoto, M. Keap1 represses nuclear activation of antioxidant responsive elements by Nrf2 through binding to the amino-terminal Neh2 domain. Genes Dev. 1999, 13, 76-86. [CrossRef] 
9. Kobayashi, A.; Kang, M.I.; Okawa, H.; Ohtsuji, M.; Zenke, Y.; Chiba, T.; Igarashi, K.; Yamamoto, M. Oxidative stress sensor Keap1 functions as an adaptor for Cul3-based E3 ligase to regulate proteasomal degradation of Nrf2. Mol. Cell. Biol. 2004, 24, 7130-7139. [CrossRef]

10. Baird, L.; Yamamoto, M. The molecular mechanisms regulating the KEAP1-NRF2 pathway. Mol. Cell. Biol. 2020, 40, e00099-20. [CrossRef]

11. Saito, R.; Suzuki, T.; Hiramoto, K.; Asami, S.; Naganuma, E.; Suda, H.; Iso, T.; Yamamoto, H.; Morita, M.; Baird, L.; et al. Characterizations of three major cysteine sensors of Keap1 in stress response. Mol. Cell. Biol. 2016, 36, 271-284. [CrossRef]

12. Otsuki, A.; Yamamoto, M. Cis-element architecture of Nrf2-sMaf heterodimer binding sites and its relation to diseases. Arch Pharm. Res. 2020, 43, 275-285. [CrossRef]

13. Katsuoka, F.; Motohashi, H.; Ishii, T.; Aburatani, H.; Engel, J.D.; Yamamoto, M. Genetic evidence that small maf proteins are essential for the activation of antioxidant response element-dependent genes. Mol. Cell. Biol. 2005, 25, 8044-8051. [CrossRef]

14. Kohle, C.; Bock, K.W. Coordinate regulation of Phase I and II xenobiotic metabolisms by the Ah receptor and Nrf2. Biochem. Pharm. 2007, 73, 1853-1862. [CrossRef]

15. Shin, S.; Wakabayashi, N.; Misra, V.; Biswal, S.; Lee, G.H.; Agoston, E.S.; Yamamoto, M.; Kensler, T.W. NRF2 modulates aryl hydrocarbon receptor signaling: Influence on adipogenesis. Mol. Cell. Biol. 2007, 27, 7188-7197. [CrossRef]

16. Miao, W.; Hu, L.; Scrivens, P.J.; Batist, G. Transcriptional regulation of NF-E2 p45-related factor (NRF2) expression by the aryl hydrocarbon receptor-xenobiotic response element signaling pathway: Direct cross-talk between phase I and II drug-metabolizing enzymes. J. Biol. Chem. 2005, 280, 20340-20348. [CrossRef]

17. Suzuki, T.; Shibata, T.; Takaya, K.; Shiraishi, K.; Kohno, T.; Kunitoh, H.; Tsuta, K.; Furuta, K.; Goto, K.; Hosoda, F.; et al. Regulatory nexus of synthesis and degradation deciphers cellular Nrf2 expression levels. Mol. Cell. Biol. 2013, 33, 2402-2412. [CrossRef]

18. Marchand, A.; Barouki, R.M.G. Regulation of NAD(P)H:quinone oxidoreductase 1 gene expression by CYP1A1 activity. Mol. Pharm. 2004, 65, 1029-1037. [CrossRef]

19. Yeager, R.L.; Reisman, S.A.; Aleksunes, L.M.; Klaassen, C.D. Introducing the "TCDD-inducible AhR-Nrf2 gene battery". Toxicol. Sci. 2009, 111, 238-246. [CrossRef]

20. Dragin, N.; Shi, Z.; Madan, R.; Karp, C.L.; Sartor, M.A.; Chen, C.; Gonzalez, F.J.; Nebert, D.W. Phenotype of the Cyp1a1/1a2/1b1-/triple-knockout mouse. Mol. Pharm. 2008, 73, 1844-1856. [CrossRef]

21. Loertscher, J.A.; Sattler, C.A.; Allen-Hoffmann, B.L. 2,3,7,8-Tetrachlorodibenzo-p-dioxin alters the differentiation pattern of human keratinocytes in organotypic culture. Toxicol. Appl. Pharm. 2001, 175, 121-129. [CrossRef] [PubMed]

22. Geusau, A.; Khorchide, M.; Mildner, M.; Pammer, J.; Eckhart, L.; Tschachler, E. 2,3,7,8-tetrachlorodibenzo-p-dioxin impairs differentiation of normal human epidermal keratinocytes in a skin equivalent model. J. Investig. Derm. 2005, 124, $275-277$. [CrossRef] [PubMed]

23. Sutter, C.H.; Bodreddigari, S.; Campion, C.; Wible, R.S.; Sutter, T.R. 2,3,7,8-Tetrachlorodibenzo-p-dioxin increases the expression of genes in the human epidermal differentiation complex and accelerates epidermal barrier formation. Toxicol. Sci. 2011, 124, 128-137. [CrossRef] [PubMed]

24. Kennedy, L.H.; Sutter, C.H.; Leon Carrion, S.; Tran, Q.T.; Bodreddigari, S.; Kensicki, E.; Mohney, R.P.; Sutter, T.R. 2,3,7,8Tetrachlorodibenzo-p-dioxin-mediated production of reactive oxygen species is an essential step in the mechanism of action to accelerate human keratinocyte differentiation. Toxicol. Sci. 2013, 132, 235-249. [CrossRef]

25. van den Bogaard, E.H.; Podolsky, M.A.; Smits, J.P.; Cui, X.; John, C.; Gowda, K.; Desai, D.; Amin, S.G.; Schalkwijk, J.; Perdew, G.H.; et al. Genetic and pharmacological analysis identifies a physiological role for the AHR in epidermal differentiation. J. Investig. Derm. 2015, 135, 1320-1328. [CrossRef]

26. Fernandez-Salguero, P.M.; Ward, J.M.; Sundberg, J.P.; Gonzalez, F.J. Lesions of aryl-hydrocarbon receptor-deficient mice. Vet. Pathol. 1997, 34, 605-614. [CrossRef]

27. Mimura, J.; Yamashita, K.; Nakamura, K.; Morita, M.; Takagi, T.N.; Nakao, K.; Ema, M.; Sogawa, K.; Yasuda, M.; Katsuki, M.; et al Loss of teratogenic response to 2,3,7,8-tetrachlorodibenzo-p-dioxin (TCDD) in mice lacking the Ah (dioxin) recepto. Genes Cells 1997, 2, 645-654. [CrossRef]

28. Schmidt, J.V.; Su, G.H.; Reddy, J.K.; Simon, M.C.; Bradfield, C.A. Characterization of a murine Ahr null allele: Involvement of the Ah receptor in hepatic growth and development. Proc. Natl. Acad. Sci. USA 1996, 93, 6731-6736. [CrossRef]

29. Haas, K.; Weighardt, H.; Deenen, R.; Kohrer, K.; Clausen, B.; Zahner, S.; Boukamp, P.; Bloch, W.; Krutmann, J.; Esser, C. Aryl hydrocarbon receptor in keratinocytes is essential for murine skin barrier integrity. J. Investig. Derm. 2016, 136, $2260-2269$. [CrossRef]

30. Takagi, S.; Tojo, H.; Tomita, S.; Sano, S.; Itami, S.; Hara, M.; Inoue, S.; Horie, K.; Kondoh, G.; Hosokawa, K.; et al. Alteration of the 4-sphingenine scaffolds of ceramides in keratinocyte-specific Arnt-deficient mice affects skin barrier function. J. Clin. Investig. 2003, 112, 1372-1382. [CrossRef]

31. Tauchi, M.; Hida, A.; Negishi, T.; Katsuoka, F.; Noda, S.; Mimura, J.; Hosoya, T.; Yanaka, A.; Aburatani, H.; Fujii-Kuriyama, Y.; et al. Constitutive expression of aryl hydrocarbon receptor in keratinocytes causes inflammatory skin lesions. Mol. Cell. Biol. 2005, 25, 9360-9368. [CrossRef] [PubMed]

32. Hidaka, T.; Ogawa, E.; Kobayashi, E.H.; Suzuki, T.; Funayama, R.; Nagashima, T.; Fujimura, T.; Aiba, S.; Nakayama, K.; Okuyama, R.; et al. The aryl hydrocarbon receptor AhR links atopic dermatitis and air pollution via induction of the neurotrophic factor artemin. Nat. Immunol. 2017, 18, 64-73. [CrossRef] 
33. Geng, S.; Mezentsev, A.; Kalachikov, S.; Raith, K.; Roop, D.R.; Panteleyev, A.A. Targeted ablation of Arnt in mouse epidermis results in profound defects in desquamation and epidermal barrier function. J. Cell. Sci. 2006, 119, 4901-4912. [CrossRef] [PubMed]

34. Wakabayashi, N.; Itoh, K.; Wakabayashi, J.; Motohashi, H.; Noda, S.; Takahashi, S.; Imakado, S.; Kotsuji, T.; Otsuka, F.; Roop, D.R.; et al. Keap1-null mutation leads to postnatal lethality due to constitutive Nrf2 activation. Nat. Genet. 2003, 35, $238-245$. [CrossRef] [PubMed]

35. Schäfer, M.; Farwanah, H.; Willrodt, A.H.; Huebner, A.J.; Sandhoff, K.; Roop, D.; Hohl, D.; Bloch, W.; Werner, S. Nrf2 links epidermal barrier function with antioxidant defense. EMBO Mol. Med. 2012, 4, 364-379. [CrossRef]

36. Schäfer, M.; Willrodt, A.H.; Kurinna, S.; Link, A.S.; Farwanah, H.; Geusau, A.; Gruber, F.; Sorg, O.; Huebner, A.J.; Roop, D.R.; et al. Activation of Nrf2 in keratinocytes causes chloracne (MADISH)-like skin disease in mice. EMBO Mol. Med. 2014, 6, $442-457$. [CrossRef] [PubMed]

37. Huebner, A.J.; Dai, D.; Morasso, M.; Schmidt, E.E.; Schafer, M.; Werner, S.; Roop, D.R. Amniotic fluid activates the nrf2/keap1 pathway to repair an epidermal barrier defect in utero. Dev. Cell. 2012, 23, 1238-1246. [CrossRef]

38. Koch, P.J.; de Viragh, P.A.; Scharer, E.; Bundman, D.; Longley, M.A.; Bickenbach, J.; Kawachi, Y.; Suga, Y.; Zhou, Z.; Huber, M.; et al. Lessons from loricrin-deficient mice: Compensatory mechanisms maintaining skin barrier function in the absence of a major cornified envelope protein. J. Cell. Biochem. 2000, 151, 389-400. [CrossRef]

39. Ishitsuka, Y.; Huebner, A.J.; Rice, R.H.; Koch, P.J.; Speransky, V.V.; Steven, A.C.; Roop, D.R. Lce1 family members are Nrf2-target genes that are induced to compensate for the loss of loricrin. J. Investig. Derm. 2016, 136, 1656-1663. [CrossRef]

40. Palmer, C.N.; Irvine, A.D.; Terron-Kwiatkowski, A.; Zhao, Y.; Liao, H.; Lee, S.P.; Goudie, D.R.; Sandilands, A.; Campbell, L.E.; Smith, F.J.; et al. Common loss-of-function variants of the epidermal barrier protein filaggrin are a major predisposing factor for atopic dermatitis. Nat. Genet. 2006, 38, 441-446. [CrossRef]

41. Henderson, J.; Northstone, K.; Lee, S.P.; Liao, H.; Zhao, Y.; Pembrey, M.; Mukhopadhyay, S.; Smith, G.D.; Palmer, C.N.; McLean, W.H.; et al. The burden of disease associated with filaggrin mutations: A population-based, longitudinal birth cohort study. $J$. Allergy Clin. Immunol. 2008, 121, 872-877.e879. [CrossRef]

42. Irvine, A.D.; McLean, W.H.I.; Leung, D.Y.M. Filaggrin mutations associated with skin and allergic diseases. N. Engl. J. Med. 2011, 365, 1315-1327. [CrossRef]

43. Weidinger, S.; O'Sullivan, M.; Illig, T.; Baurecht, H.; Depner, M.; Rodriguez, E.; Ruether, A.; Klopp, N.; Vogelberg, C.; Weiland, S.K.; et al. Filaggrin mutations, atopic eczema, hay fever, and asthma in children. J. Allergy Clin. Immunol. 2008, 121, 1203-1209.e1201. [CrossRef]

44. Eichenfield, L.F.; Tom, W.L.; Chamlin, S.L.; Feldman, S.R.; Hanifin, J.M.; Simpson, E.L.; Berger, T.G.; Bergman, J.N.; Cohen, D.E.; Cooper, K.D.; et al. Guidelines of care for the management of atopic dermatitis: Section 1. Diagnosis and assessment of atopic dermatitis. J. Am. Acad. Derm. 2014, 70, 338-351. [CrossRef]

45. Nutten, S. Atopic dermatitis: Global epidemiology and risk factors. Ann. Nutr. Metab. 2015, 66 (Suppl. S1), 8-16. [CrossRef]

46. Deckers, I.A.; McLean, S.; Linssen, S.; Mommers, M.; van Schayck, C.P.; Sheikh, A. Investigating international time trends in the incidence and prevalence of atopic eczema 1990-2010: A systematic review of epidemiological studies. PLoS ONE 2012, 7, e39803. [CrossRef]

47. Stander, S. Atopic dermatitis. N. Engl. J. Med. 2021, 384, 1136-1143. [CrossRef]

48. Roberts, W. Air pollution and skin disorders. Int. J. Womens Derm. 2021, 7, 91-97. [CrossRef]

49. Kim, J.; Kim, E.H.; Oh, I.; Jung, K.; Han, Y.; Cheong, H.K.; Ahn, K. Symptoms of atopic dermatitis are influenced by outdoor air pollution. J. Allergy Clin. Immunol. 2013, 132, 495-498.e491. [CrossRef]

50. Song, S.; Lee, K.; Lee, Y.M.; Lee, J.H.; Lee, S.I.; Yu, S.D.; Paek, D. Acute health effects of urban fine and ultrafine particles on children with atopic dermatitis. Environ. Res. 2011, 111, 394-399. [CrossRef]

51. Ngoc, L.T.N.; Park, D.; Lee, Y.; Lee, Y.C. Systematic review and meta-analysis of human skin diseases due to particulate matter. Int. J. Environ. Res. Public Health 2017, 14, 1458. [CrossRef] [PubMed]

52. Kim, B.E.; Kim, J.; Goleva, E.; Berdyshev, E.; Lee, J.; Vang, K.A.; Lee, U.H.; Han, S.; Leung, S.; Hall, C.F.; et al. Particulate matter causes skin barrier dysfunction. JCI Insight 2021, 6, e145185. [CrossRef] [PubMed]

53. Mueller, D.; Uibel, S.; Braun, M.; Klingelhoefer, D.; Takemura, M.; Groneberg, D.A. Tobacco smoke particles and indoor air quality (ToPIQ)-the protocol of a new study. J Occup. Med. Toxicol. 2011, 6, 35. [CrossRef] [PubMed]

54. Egawa, M.; Kohno, Y.; Kumano, Y. Oxidative effects of cigarette smoke on the human skin. Int. J. Cosmet. Sci. 1998, 21, 83-98. [CrossRef] [PubMed]

55. Kantor, R.; Kim, A.; Thyssen, J.P.; Silverberg, J.I. Association of atopic dermatitis with smoking: A systematic review and meta-analysis. J. Am. Acad. Derm. 2016, 75, 1119-1125.e1111. [CrossRef]

56. Ng, Y.T.; Chew, F.T. A systematic review and meta-analysis of risk factors associated with atopic dermatitis in Asia. World Allergy Organ. J. 2020, 13, 100477. [CrossRef]

57. Suzuki, T.; Hidaka, T.; Kumagai, Y.; Yamamoto, M. Environmental pollutants and the immune response. Nat. Immunol. 2020, 21, 1486-1495. [CrossRef]

58. Edamitsu, T.; Taguchi, K.; Kobayashi, E.H.; Okuyama, R.; Yamamoto, M. Aryl hydrocarbon receptor directly regulates artemin gene expression. Mol. Cell. Biol. 2019, 39, e00190-19. [CrossRef] 
59. Kim, H.O.; Kim, J.H.; Chung, B.Y.; Choi, M.G.; Park, C.W. Increased expression of the aryl hydrocarbon receptor in patients with chronic inflammatory skin diseases. Exp. Derm. 2014, 23, 278-281. [CrossRef]

60. van den Bogaard, E.H.; Bergboer, J.G.; Vonk-Bergers, M.; van Vlijmen-Willems, I.M.; Hato, S.V.; van der Valk, P.G.; Schroder, J.M.; Joosten, I.; Zeeuwen, P.L.; Schalkwijk, J. Coal tar induces AHR-dependent skin barrier repair in atopic dermatitis. J. Clin. Investig. 2013, 123, 917-927. [CrossRef]

61. Peppers, J.; Paller, A.S.; Maeda-Chubachi, T.; Wu, S.; Robbins, K.; Gallagher, K.; Kraus, J.E. A phase 2, randomized dose-finding study of tapinarof (GSK2894512 cream) for the treatment of atopic dermatitis. J. Am. Acad. Derm. 2019, 80, 89-98.e83. [CrossRef]

62. Paller, A.S.; Stein Gold, L.; Soung, J.; Tallman, A.M.; Rubenstein, D.S.; Gooderham, M. Efficacy and patient-reported outcomes from a phase $2 \mathrm{~b}$, randomized clinical trial of tapinarof cream for the treatment of adolescents and adults with atopic dermatitis. $J$. Am. Acad. Derm. 2021, 84, 632-638. [CrossRef]

63. Smith, S.H.; Jayawickreme, C.; Rickard, D.J.; Nicodeme, E.; Bui, T.; Simmons, C.; Coquery, C.M.; Neil, J.; Pryor, W.M.; Mayhew, D.; et al. Tapinarof is a natural AhR agonist that resolves skin inflammation in mice and humans. J. Investig. Derm. 2017, 137, 2110-2119. [CrossRef]

64. Shimizu, S.; Mimura, J.; Hasegawa, T.; Shimizu, E.; Imoto, S.; Tsushima, M.; Kasai, S.; Yamazaki, H.; Ushida, Y.; Suganuma, H.; et al. Association of single nucleotide polymorphisms in the NRF2 promoter with vascular stiffness with aging. PLoS ONE 2020, 15, e0236834. [CrossRef]

65. Tadaka, S.; Saigusa, D.; Motoike, I.N.; Inoue, J.; Aoki, Y.; Shirota, M.; Koshiba, S.; Yamamoto, M.; Kinoshita, K. jMorp: Japanese Multi Omics Reference Panel. Nucleic Acids Res. 2018, 46, D551-D557. [CrossRef] [PubMed]

66. Marzec, J.M.; Christie, J.D.; Reddy, S.P.; Jedlicka, A.E.; Vuong, H.; Lanken, P.N.; Aplenc, R.; Yamamoto, T.; Yamamoto, M.; Cho, H.Y.; et al. Functional polymorphisms in the transcription factor NRF2 in humans increase the risk of acute lung injury. FASEB J. 2007, 21, 2237-2246. [CrossRef]

67. Honkura, Y.; Matsuo, H.; Murakami, S.; Sakiyama, M.; Mizutari, K.; Shiotani, A.; Yamamoto, M.; Morita, I.; Shinomiya, N.; Kawase, T.; et al. NRF2 Is a key target for prevention of noise-induced hearing loss by reducing oxidative damage of cochlea. Sci. Rep. 2016, 6, 19329. [CrossRef]

68. Bouligand, J.; Cabaret, O.; Canonico, M.; Verstuyft, C.; Dubert, L.; Becquemont, L.; Guiochon-Mantel, A.; Scarabin, P.Y. Effect of NFE2L2 genetic polymorphism on the association between oral estrogen therapy and the risk of venous thromboembolism in postmenopausal women. Clin Pharm. Ther. 2011, 89, 60-64. [CrossRef]

69. Cho, H.Y.; Marzec, J.; Kleeberger, S.R. Functional polymorphisms in Nrf2: Implications for human disease. Free Radic. Biol. Med. 2015, 88, 362-372. [CrossRef]

70. Fukushima-Uesaka, H.; Saito, Y.; Maekawa, K.; Kawatani, N.; Kajio, H.; Kuzuya, N.; Noda, M.; Yasuda, K.; Sawada, J. Genetic variations and haplotype structures of transcriptional factor Nrf2 and its cytosolic reservoir protein Keap1 in Japanese. Drug. Metab. Pharmacokinet. 2007, 22, 212-219. [CrossRef]

71. Gui, Y.; Zhang, L.; Lv, W.; Zhang, W.; Zhao, J.; Hu, X. NFE2L2 variations reduce antioxidant response in patients with Parkinson disease. Oncotarget 2016, 7, 10756-10764. [CrossRef] [PubMed]

72. Wang, I.J.; Guo, Y.L.; Lin, T.J.; Chen, P.C.; Wu, Y.N. GSTM1, GSTP1, prenatal smoke exposure, and atopic dermatitis. Ann. Allergy Asthma Immunol. 2010, 105, 124-129. [CrossRef]

73. Fukushima-Uesaka, H.; Sai, K.; Maekawa, K.; Koyano, S.; Kaniwa, N.; Ozawa, S.; Kawamoto, M.; Kamatani, N.; Komamura, K.; Kamakura, S.; et al. Genetic variations of the AHR gene encoding aryl hydrocarbon receptor in a Japanese population. Drug. Metab. Pharm. 2004, 19, 320-326. [CrossRef] [PubMed]

74. Wang, X.W.; Li, K.; Guo, S.; Qiang, H.N.; Liu, L.; Song, P.; Wei, C.; Yi, X.L.; Jian, Z.; Li, Q.; et al. The association of functional polymorphisms in the aryl hydrocarbon receptor (AHR) gene with the risk of vitiligo in Han Chinese populations. Br. J. Derm. 2012, 166, 1081-1087. [CrossRef]

75. Chen, D.; Tian, T.; Wang, H.; Liu, H.; Hu, Z.; Wang, Y.; Liu, Y.; Ma, H.; Fan, W.; Miao, R.; et al. Association of human aryl hydrocarbon receptor gene polymorphisms with risk of lung cancer among cigarette smokers in a Chinese population. Pharm. Genom. 2009, 19, 25-34. [CrossRef]

76. Huang, S.; Shui, X.; He, Y.; Xue, Y.; Li, J.; Li, G.; Lei, W.; Chen, C. AhR expression and polymorphisms are associated with risk of coronary arterial disease in Chinese population. Sci. Rep. 2015, 5, 8022. [CrossRef]

77. Sangrajrang, S.; Sato, Y.; Sakamoto, H.; Ohnami, S.; Laird, N.M.; Khuhaprema, T.; Brennan, P.; Boffetta, P.; Yoshida, T. Genetic polymorphisms of estrogen metabolizing enzyme and breast cancer risk in Thai women. Int. J. Cancer 2009, 125, 837-843. [CrossRef]

78. Smart, J.; Daly, A.K. Variation in induced CYP1A1 levels: Relationship to CYP1A1, Ah receptor and GSTM1 polymorphisms. Pharmacogenetics 2000, 10, 11-24. [CrossRef]

79. Koyano, S.; Saito, Y.; Fukushima-Uesaka, H.; Ishida, S.; Ozawa, S.; Kamatani, N.; Minami, H.; Ohtsu, A.; Hamaguchi, T.; Shirao K.; et al. Functional analysis of six human aryl hydrocarbon receptor variants in a Japanese population. Drug. Metab. Dispos. 2005, 33, 1254-1260. [CrossRef]

80. Wong, J.M.Y.; Harper, P.A.; Meyer, U.A.; Bock, K.W.; Morike, K.; Lagueux, J.; Ayotte, P.; Tyndale, R.F.; Sellers, E.M.; Manchester, D.K.; et al. Ethnic variability in the allelic distribution of human aryl hydrocarbon receptor codon 554 and assessment of variant receptor function in vitro. Pharmacogenetics 2001, 11, 85-94. [CrossRef] 
81. Ma, Q.; Baldwin, K.T. 2,3,7,8-tetrachlorodibenzo-p-dioxin-induced degradation of aryl hydrocarbon receptor (AhR) by the ubiquitin-proteasome pathway. Role of the transcription activaton and DNA binding of AhR. J. Biol. Chem. 2000, 275, 8432-8438. [CrossRef] [PubMed]

82. Li, D.; Takao, T.; Tsunematsu, R.; Morokuma, S.; Fukushima, K.; Kobayashi, H.; Saito, T.; Furue, M.; Wake, N.; Asanoma, K. Inhibition of AHR transcription by NF1C is affected by a single-nucleotide polymorphism, and is involved in suppression of human uterine endometrial cancer. Oncogene 2013, 32, 4950-4959. [CrossRef] [PubMed]

83. Liu, G.; Asanoma, K.; Takao, T.; Tsukimori, K.; Uchi, H.; Furue, M.; Kato, K.; Wake, N. Aryl hydrocarbon receptor SNP-130 C/T associates with dioxins susceptibility through regulating its receptor activity and downstream effectors including interleukin 24 . Toxicol. Lett. 2015, 232, 384-392. [CrossRef]

84. Li, Z.Z.; Zhong, W.L.; Hu, H.; Chen, X.F.; Zhang, W.; Huang, H.Y.; Yu, B.; Dou, X. Aryl hydrocarbon receptor polymorphisms are associated with dry skin phenotypes in Chinese patients with atopic dermatitis. Clin. Exp. Derm. 2019, 44, 613-619. [CrossRef]

85. Thijs, J.L.; Strickland, I.; Bruijnzeel-Koomen, C.; Nierkens, S.; Giovannone, B.; Csomor, E.; Sellman, B.R.; Mustelin, T.; Sleeman, M.A.; de Bruin-Weller, M.S.; et al. Moving toward endotypes in atopic dermatitis: Identification of patient clusters based on serum biomarker analysis. J. Allergy Clin. Immunol. 2017, 140, 730-737. [CrossRef]

86. Yew, Y.W.; Thyssen, J.P.; Silverberg, J.I. A systematic review and meta-analysis of the regional and age-related differences in atopic dermatitis clinical characteristics. J. Am. Acad. Derm. 2019, 80, 390-401. [CrossRef]

87. Kong, T.S.; Han, T.Y.; Lee, J.H.; Son, S.J. Correlation between severity of atopic dermatitis and sleep quality in children and adults. Ann. Derm. 2016, 28, 321-326. [CrossRef]

88. Fuse, N.; Sakurai-Yageta, M.; Katsuoka, F.; Danjoh, I.; Shimizu, R.; Tamiya, G.; Nagami, F.; Kawame, H.; Higuchi, S.; Kinoshita, K.; et al. Establishment of integrated biobank for precision medicine and personalized healthcare: The tohoku medical megabank project. JMA J. 2019, 2, 113-122. [CrossRef] 